\title{
Örgütsel Sessizlik ve Tükenmişliğin Psikolojik Sözleşme İhlali Üzerindeki Etkilerine Yönelik Bir Araştırma
}

\author{
DOI: 10.26466/opus.594613
}

\author{
Fatma Yilmaz \\ * Dr. Öğr. Üyesi, Erzincan Binali Yıldırım Üniversitesi, Üzümlü MYO, Üzümlü/Erzincan/Türkiye \\ E-Posta: ffatmaayilmaz@gmail.com \\ ORCID: $\underline{0000-0001-8065-7245}$
}

\section{Öz}

Bu çalışmada örgütsel sessizlik, tükenmişlik ve psikolojik sözleşme ihlali ilişkisi incelenmiştir. Bu çalışma ile işgörenlerin işletme içerisindeki sessizlikleri ve tükenmişliklerinin psikolojik sözleşme ihlaline yol açıp açmadığı amaçlanmaktadır. Bu doğrultuda örgütsel sessizliğin alt boyutlarn olan kabullenici sessizlik, korunmacı sessizlik, korumacı sessizlik ile tükenmişliğin alt boyutlar olan duygusal tükenme ve duyarsızlaşmanın psikolojik sözleşme ihlalini etkileyip etkilemediği incelenmiştir. Bu ilişkiyi belirleyebilmek için çalışanlara anket uygulaması gerçekleştirilmiştir. Elde edilen veriler SPSS paket programı aracılığı ile yorumlanmıştır. Çalışmanın ilk bölümünde örgütsel sessizlik, tükenmişlik ve psikolojik sözleşme ihlalini açıklamaya yönelik literatür taraması yapılmıştır. İkinci bölümünde örgütsel sessizlik ve tükenmişliğin, psikolojik sözleşme ihlali üzerindeki etkileri ve değiş̧kenlerin demografik veriler ile olan ilişkileri açıklanmıştır. Bu doğrultuda korelasyon, regresyon ve Anova analizleri gerçekleştirilmiştir. Yapılan analiz sonuçlarına göre örgütsel sessizlik ve alt boyutlar olan kabullenici sessizlik, korunmact sessizlik ve korumacı sessizlik ile psikolojik sözleşme ihlalini kuvvetli bir biçimde etkilemektedir. Tükenmişliğin alt boyutlarnnda ise sadece kişisel başarı hissinde azalma oldukça psikolojik sözleşme ihlali artmaktadır.

Anahtar Kelimeler: Örgütsel sessizlik, tükenmişlik, psikolojik sözleşme ihlali 


\title{
A Research on the Effects of Organizational Silence and Burnout on Psychological Contract Violation
}

\begin{abstract}
In this study, the relationship between organizational silence, burnout and violation of psychological contract was examined. The aim of this study is to determine whether the silence and burnout of the employees in the enterprise cause psychological contract violations. In this direction, whether the sub-dimensions of organizational silence, acceptive silence, protective silence, protective silence and emotional exhaustion and depersonalization, which are the sub-dimensions of burnout, affect the violation of psychological contract.In order to determine this relationship, a questionnaire was applied to the employees. The data obtained were interpreted by means of SPSS package program. In the first part of the study, a literature review was conducted to explain organizational silence, burnout and psychological contract violations. In the second part, the effects of organizational silence and burnout on the violation of psychological contract and the relationship between variables and demographic data are explained. Correlation, regression and Anova analyzes were performed. According to the results of the analysis, organizational silence and accepted silence, which have sub-dimensions, preventive silence and protective silence, strongly affect the violation of psychological contract. In the sub-dimensions of burnout, psychological contract violations increase only when the feeling of personal accomplishment decreases.
\end{abstract}

Keywords: Organizational silence, burnout, violation of psychological contract, 


\section{Giriş}

Rekabet koşullarının zorlaştığı ve küreselleşme sayesinde sınırların iyice belirsizleştiği modern ekonomik dünyada, çalışanların ifade özgürlüklerinin artması, yaratıcılıklarının yükselmesi ve daha çok sorumluluk bilincine sahip olmaları beklenir (Quinn ve Spreitzer, 1997, s.36). Günümüzde işletmelerin en büyük hedeflerinden birisi çalışanlarının bilgi, beceri ve yeteneklerini sürekli olarak geliştirmeleri ve onların kurum için gerekli olan en doğru bilgiye ulaşmalarıdır. Fakat örgüt içerisinde yer alan işgörenlerin birbirleriyle olan ilişkileri sonucunda farklı davranışlar ortaya çıkmaktadır. İşgörenler bu süreçte birbirleri ile yakın ilişkiler kurabileceği gibi, birbirlerinden uzaklaşabilmektedir. Oysa örgüt içerisinde önceden belirlenen hedeflere ulaşabilmek için örgütte yer alan işgörenler arasındaki ilişkilerin ve iletişimin geliştirilmesi oldukça önemlidir. Buna karşın örgüt içerisinde işgörenlerin her zaman iyi iletişim kuramadıkları, çekindikleri ya da diğer işgörenlere karşı mesafeli davranışlar sergiledikleri bilinmektedir (Demir ve Demir, 2012, s.85). Bu durum çalışan sessizliği, tükenmişlik gibi olumuz durumlara neden olabilmektedir.

Örgütsel sessizlik kavramı; işgörenin üyesi bulunduğu işletmenin mevcut durumuna dair duygusal, davranıssal ve zihinsel söylemlerini, ilgililer ile paylaşmaktan kaçınması biçiminde açıklanmaktadır (Pinder ve Harlos, 2001: 334). Örgütsel sessizlik örgütlerde karşılaş1lan problemlerle ilgili işgörenlerin ortak ve kasıtlı olarak tepki vermemeleri, duygu ve düşüncelerini başkaları ile paylaşmamaları olarak da tanımlanmaktadır (Ülker ve Kanter, 2009, s.111). Örgütsel sessizlik, çalışanların işyerleri ya da işleri ile ilgili davranışsal sorunlar veya teknik sorunlarla ilgili görüş, düşünce ve bilgilerini bilinçli bir şekilde üstlerine iletmeyerek suskun kalmalarıdır (Çakıcı, 2010, s.91).

Sessizliğin yaygın olduğu işletmelerde gelişim zayıf, değişim yetersizdir. İnnovasyon faaliyetleri yeterli olmamaktadır. Çalışanların motivasyonu, iş tatmini, iş sadakati ve üretkenliği düşüktür. Çalışanlar birbirlerinden uzaklaşmaktadır. Kurum kararların etkinliği azalmakta işten ayrılmalar artarak tecrübe ve üretkenlikten uzun dönemli faydalanma ihtimali düşmektedir (Civelek vd. 2015, s.42). Çalışanların, kurumda pasif kalmaları, motivasyonlarını, morallerini ve güvenlerini zayıflatmaktadır. Kişilerin, kurumun yararına dahi olsa fikirlerini söylemekten kaçınmaları, 
problemleri görmeleri halinde bunu dile getirmemeleri kurumun maddi ve manevi zarara uğramasına sebebiyet vermektedir (Vakola ve Bouradas, 2005, s.443). Örgütsel sessizlik sürecinde, örgüt içerisinde olumsuz dönütler, doğru bilginin alınamaması ve farklı görüşlerin ortaya çıkmaması durumları yaşanarak örgüt adına karar verme süreci olumsuz etkilenmektedir (Ehtiyar ve Yanardağ, 2008, s.52).

Örgütsel sessizlik türleri şu şekildedir; kabullenici sessizlik, korunmacı sessizlik ve korumacı sessizliktir (Çakıcı, 2008, s.97).

Kabullenici sessizlik; bu sessizlik türünde yer alan kişiler, mevcut durumu değiştirmeye yeltenmez ve konuyla alakalı konuşma gibi bir çaba içine de girmez. Bu türde, kişinin bilerek pasif ve ilgisiz kalması söz konusudur (Çakıcı, 2008, s.87). Kişiler, olayları olduğu gibi kabul eder ve değiştirme, daha iyisi için alternatifler sunma gibi yöntemleri dikkate almazlar. Mevcut durumu kabul edip, huzursuzluk çıkarmama çalışana kurum içinde güven duygusunu vermektedir ve bu yüzden çalışan güven ortamını bozmaktan kaçınmaktadır (Pinder ve Harlos, 2001, s.349).

Korunmacı sessizlik; çalışanın, bir sorun hakkındaki düşüncelerini belirtmesi durumunda, gelecek tepkilerden korkarak kendini korumak için sessiz kalmayı seçmesidir (Dyne, Ang ve Botero, 2003, s.1367).

Korumacı sessizlik; bireyin, iş arkadaşlarını düşünerek, kuruma ve iş arkadaşlarına olumlu bir etkide bulunabilmek için, sorun veya olaylar karşısında düşüncelerini ifade etmemesi olarak tanımlanabilir. Aynı korunmacı sessizlikte olduğu gibi, kişinin düşüncelerini bilinçli bir biçimde saklamasıdır (Dyne, Ang ve Botero, 2003, s.1368). Korunmacı sessizlikten farklı olarak bu türde çalışan kendi adına korkusundan değil kurum çalışanlarına zarar vermemek amacıyla sessiz kalmayı tercih etmektedir. Çalışanların sessiz kalması karşısında yöneticiler bunun nedenini anlamayabilir fakat yöneticinin amacı, bu nedeni bulmak ve örgüt içindeki iletişimi aktif hale getirmek olmalıdır (Çakıcı, 2008, s.99-100).

İşgörenlerde ortaya çıabilecek bir diğer olumsuz durum tükenmişliktir. Tükenmişlik kavramı, bireylerin meslek olarak yaptıkları işlerin özünden uzaklaşması ve hizmet verdiği insanlar ile ilgilenmemesi veya doyumsuzluğa ve aşırı strese tepki olarak kendilerini işlerinden geri çekmeleri ve soğumalarıdır (Kaçmaz, 2005, s.29; Çetin, 2017, s.84-85). Freudenberger tükenmişliği; "başarısız olma, yıpranma, enerji ve gücün 
azalması veya tatmin edilemeyen istekler sonucunda bireyin iç kaynaklarında meydana gelen tükenme durumu" olarak tanımlayarak (Freudenberger, 1974, s.159). Maslach ve Jackson (1981) tükenmişliği; yardım hizmeti talep edilen bireylerin maruz kaldıkları duygusal tükenme, duyarsızlaşma ve kişisel başarının düşmesini içeren bir sendrom olarak tanımlamaktadır.

Bu tanım tükenmişlik kavramının 3 boyutunu da kapsamaktadır. Bu boyutlar "duyarsızlaşma", "kişisel başarısının gerilemesi" ve "duygusal olarak tükenme" şeklindedir (Maslach vd., 2001, s.398).

Duygusal tükenme boyutunda birey yorgunluk, enerji düşmesi ve duygusal olarak bitkinlik gibi belirtiler göstermektedir. Bu boyut tükenmişliğin içsel boyutu olarak görülmektedir. Duygusal anlamda tükenmişlik yaşayan işgörenler, hizmet verdikleri kişilere karşı eskisi kadar sorumlu davranışlar sergilemediklerini düşünür, bununla birlikte engellenmişlik ve stres durumları yaşayan bireylerde aynı işe gitme zorunluluğu endişeye sebep olmaktadır (Maslach ve diğerleri, 2001). Duygusal tükenme en basit olarak, "duygusal kaynakların tükenmesi" olarak ifade edilmektedir (Akın ve Oğuz, 2010, s.314). Duygusal tükenme; tükenmişliğin en fazla öneme sahip olan öğesi, başlangıcı ve odağıdır. Bu öğe, iş kaynaklı gerginlikle daha çok alakalıdır. Sıkışık bir tempoda çalışan birey, duygusal olarak kendini aşırı yormakta ve başkalarının talepleri karşısında ezilmişlik hissetmektedir. Tükenmişlik, bu şartlara karşı bir reaksiyon olarak yaşanmaktadır (Üngüren vd., 2010, s.2924).

Duyarsızlaşma boyutunda işgörenler, hizmet sundukları bireylere ve aynı zamanda çalıştıkları işletmeye karşı mesafeli, umursamayan bir davranış ortaya koyabilirler ve böyle davrandıkları için de herhangi bir rahatsızlık hissetmezler. (Çimen, 2000, s.6). Duyarsızlaşma; işgörenlerin hizmet verdikleri kişilere karşı duygudan yoksun bir biçimde davranış ve tutumlar sergilemeleridir (Dolunay, 2002, s.53).

Kişisel başarı hissinde azalma boyutunda birey iş hayatına başlarken olduğu hali ile şimdiki hali arasındaki farkları görmeye ve yetersiz olduğunu değerlendirmeye başlar. Birey kişisel olarak başarısızlık ve kişisel yetersizlik duygusu içinde olduğu sonucuna ulaşır. Bu durumdaki birey, sarf ettiği çabanın bir işe yaramayacağına inanarak, kendisine olan saygısını kaybedip, takdir edilmediğini düşünmeye başlamaktadır (Basım ve Şeşen, 2006, s.18). Düşük kişisel başarının diğer özellikleri düşük 
moral, kişilerarası anlaşmazlık, düşük verimlilik, problemlerle mücadele etmede yetersizlik ve öz sayg1 azalmasını içerir (Demirci, 2018, s.21-22).

Psikolojik sözleşme kavramı tarafların yükümlülükleri algılama biçimine bağlı olarak ortaya çıkan bir kavramdır (Walker ve Hutton, 2006, s.434).

Psikolojik sözleşme; esnekliğin hakim olduğu ve değişimin hüküm sürdüğü çalışma yaşamında, insan ihtiyaçlarının anlaşılmasını kolaylaştıracak fırsatlar sunması açısından önem arz etmektedir. Ayrıca bazı yazarlara göre örgütsel yaşamın temel unsuru olan çalışan - işveren ilişkisinin yeniden incelenmesi için farklı bir pencere sunmaktadır (CoyleShapiro ve Kessler, 2000, s.903). Psikolojik sözleşme ihlali, psikolojik sözleşmenin yerine getirilmeme derecesiyle ilgili olarak, çalışanda oluşan olumsuz algilar toplamıdır (Tyagi ve Agrawal, 2010, s.385). Psikolojik sözleşme ihlal algısı ise bireylerde duygusal çözülmeler, aldatılmışlık hissi, örgütsel çıkarlar uğruna iyi niyetinin kötüye kullanılması hissi, öfke, hayal kırıklığı, adaletsizlik ve eşitsizlik gibi çeşitli sonuçlara yol açabilmektedir (Rousseau, 1989, s.29). Çalışanın örgütsel yapı, örgütsel süreçler, örgütsel hedefler, etkinlik, performans geribildirimi, kalite ve üretim hakkında uygulanan baskı derecesi hakkındaki algı ve düşünceleri, bireyde psikolojik sözleşme ihlalinin oluşup oluşmayacağına yön vermektedir (Hartmann, 2012, s.44). psikolojik sözleşme ihlal algısının belki de en önemli olumsuz etkisi, örgüt ile çalışan arasındaki iş ilişkisinin temeli olan güven duygusunu zedelemesidir (Bal, vd., 2008, s.144).

Psikolojik sözleşme ihlalinin oluşmasına neden olan faktörler farklı şekillerde ortaya çıkabilmektedir. Bunlar (Liao-Troth, 1999, s.22; Tükeltürk, vd., 2012, s.94); çalışanlara eğitim ve gelişim imkânlarının sağlanmaması ya da yeterli eğitimin verilmemesi, verilen maaşlar ile vaat edilen maaşlar arasındaki tutarsızlık, terfilerin planlanan doğrultuda gerçekleşmemesi, yöneticilerin çalışanlara yanlış ya da eksik bilgi vermesi, iş güvenliği derecesinin vaat edilen gibi olmaması, geribildirimin yetersiz yapılması veya hiç yapılmaması, örgütsel değişim süreçlerinde çalışanın fikrinin alınmaması veya bu değişimden habersiz olması, çalışanlara olması gerekenden daha az sorumluluk veriliyor olmasıdır.

Psikolojik sözleşmenin türleri açısından psikolojik sözleşme ihlal algısının sonuçları incelendiğinde ilginç sonuçlar ortaya çıktığı görülmektedir. Çalışan kurumundan hak ettiğini düşündüğü maaşı, primi veya ücret artışını alamadığında (işlemsel sözleşme ihlali) iş tatmininde azalma 
tespit edildiği belirtilmiştir. Çalışan örgütsel karar verme süreçlerine dahil edilmediğine, geri bildirim yapılmadığına veya eğitim desteğinden mahrum bırakıldığına kanaat getirirse (ilişkisel sözleşme ihlali) örgütsel bağlılı̆̆ının düşeceği ifade edilmiştir (Anderson ve Schalk, 1998, s.641). Psikolojik sermaye kavramı stres, tükenmişlik, çatışma, örgüt içi kopuk ilişkiler gibi yani kısaca psikolojik sözleşme ihlallerinde ortaya çıkması muhtemel duygu ve durumlar ile negatif ilişkilidir (Luthans vd., 2007, s.148).

\section{Yöntem}

\section{Araştırma Modeli}

$\mathrm{Bu}$ çalışma iki veya daha fazla sayıdaki değişkenler arasında birlikte değişimin varlığını veya düzeyini belirleme amacı ile kullanılan ilişkisel tarama modeli ile oluşturulmuştur. Çalışma, örgütsel sessizlik ve tükenmişliğin psikolojik sözleşme ihlali üzerindeki etkilerini belirlemeye yönelik olarak tasarlanmıştır. Araştırmanın temel bağımsız değişkenleri örgütsel sessizlik ve tükenmişlik iken bağımlı değişkeni psikolojik sözleşme ihlalidir.

Araştırmanın modeli şekil 1'de gösterilmiştir.

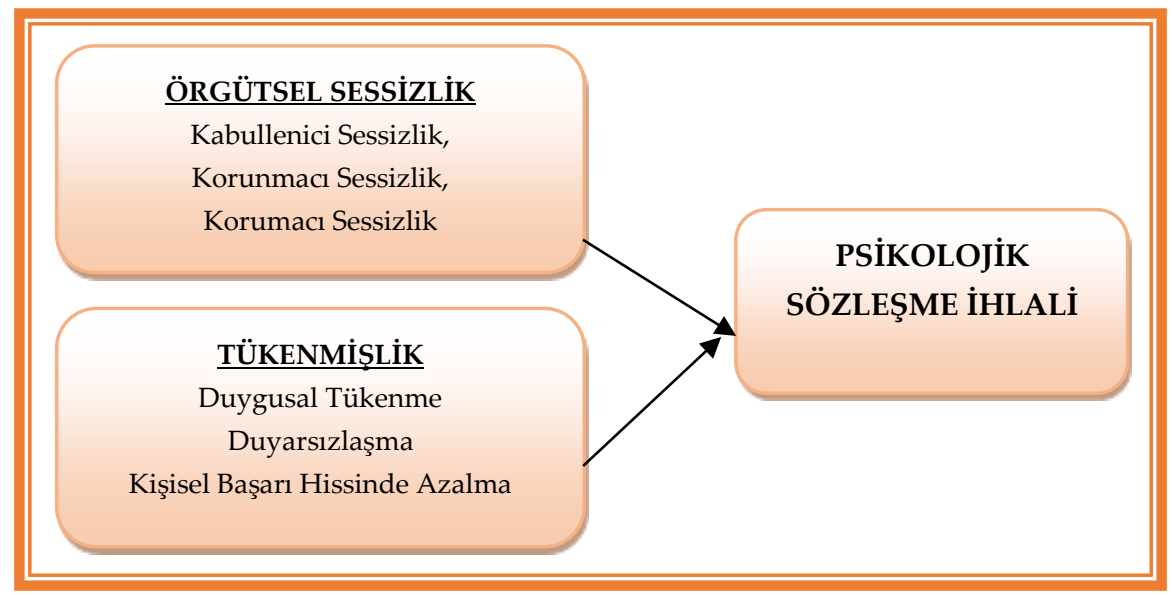

Şekil 1. Araştırma Modeli 
Araştırmanın amacına hitap etmesi bakımından belirlenen hipotezler aşağıdaki gibidir:

- H1: Kabullenici sessizlik psikolojik sözleşme ihlali üzerinde istatistiki olarak anlamlı bir etkiye sahiptir.

- H2: Korunmacı sessizlik psikolojik sözleşme ihlali üzerinde istatistiki olarak anlamlı bir etkiye sahiptir.

- H3: Korumacı sessizlik psikolojik sözleşme ihlali üzerinde istatistiki olarak anlamlı bir etkiye sahiptir.

- H4: Duygusal tükenme psikolojik sözleşme ihlali üzerinde istatistiki olarak anlamlı bir etkiye sahiptir.

- H5: Duyarsızlaşma psikolojik sözleşme ihlali üzerinde istatistiki olarak anlamlı bir etkiye sahiptir.

- H6: Kişisel başarı hissinde azalma psikolojik sözleşme ihlali üzerinde istatistiki olarak anlamlı bir etkiye sahiptir.

\section{Araştırmanın Amacı}

Bu çalışma ile işgörenlerin işletme içerisindeki sessizlikleri ve tükenmişliklerinin psikolojik sözleşme ihlaline yol açıp açmadığı amaçlanmaktadır. Bu doğrultuda örgütsel sessizliğin alt boyutları olan kabullenici sessizlik, korunmacı sessizlik, korumacı sessizlik ile tükenmişliğin alt boyutları olan duygusal tükenme ve duyarsızlaşmanın psikolojik sözleşme ihlalini etkileyip etkilemediği irdelenmektedir.

\section{Araştırma Örneklemi ve Veri Toplama Yöntemi}

Çalışmanın örneklemini bir üretim işletmesinde çalışmakta olan 226 işgören oluşturmaktadır. Örnekleme yöntemi kolayda örneklemdir. Veri toplama yöntemi olarak anket yöntemi kullanılmıştır. Oluşturulan anket formu 2019 yılı şubat ayında çalışanlara elden dağıtılmıştır. Dağıtılan 400 anket formunun 241'i geri toplanmıştır. Bunlardan hatalı doldurulanlar çıkarıldıktan sonra 226 anket sonucu veri olarak kullanılmıştır. Anketlerin geri dönüş oranı 56,5'tir. 


\section{Araştırmada Kullanılan Ölçekler}

Anketin ilk kısmında demografik bilgileri ölçmeye yönelik olarak 5 soru ikinci kısmında örgütsel sessizliği ölçmeye yönelik 15 soru, tükenmişliği ölçmeye yönelik 22 soru ve psikolojik sözleşme ihlalinin ölçmeye yönelik 9 soru olmak üzere toplamda 51 soru bulunmaktadır. Kullanılan ölçekler 5'li likert şeklinde düzenlenmiştir. 1=kesinlikle katılmıyorun, 5=kesinlikle katılıyorum şeklindedir.

Örgütsel sessizlik ölçeği; çalışanların örgütsel sessizlik düzeylerini belirlemek amaciyla Dyne, vd., (2003) tarafından geliştirilen ve Taşkıran (2011) tarafından Türkçe'ye uyarlanan "Örgütsel Sessizlik Ölçeği" kullanılmıştır. Ölçek kabullenici sessizlik, korunmacı sessizlik, korumacı sessizlik şeklinde 3 alt boyuttan ve 15 maddeden oluşmaktadır.

Tükenmişlik ölçeği; Maslach ve Jackson (1981) tarafından geliştirilen tükenmişlik ölçeği, duygusal tükenme 9 soru, duyarsızlaşma 5 soru ve kişisel başarı eksikliği 8 soru şeklinde 22 maddeden ve üç alt boyuttan oluşmaktadır.

Psikolojik sözleşme ihlal algı ölçeği; Robinson ve Rousseau (1994) tarafından geliştirilmiştir. 9 maddeli ölçek, katılanların işverenlerinin onlara karşı yükümlülüklerini yerine getirip getirmediğine ilişkin algılarını ölçmek üzere planlanmıştır. Ankete katılanların işverenlerinin onlara karşı yükümlülüklerini yerine getirip getirmediği algılarını ölçmek üzere planlanmıştır. Eğitim-geliştirme, ücretler, terfi, işin doğası, iş güvenliği, geri besleme, değişimin yönetimi, kişisel sorumluluk alarak kendini gösterme fırsatları, çalışanların uzmanlık durumu ve birlikte çalışma niteliklerinin söz verildiği gibi olup olmadığını değerlendirilmektedir.

\section{Bulgular}

Araştırmanın bu bölümünde katılımcılara ait sosyo-demografik değişkenler yüzde ve frekans analizlerine tabi tutulmuştur. Örgütsel sessizlik ve tükenmişliğin ve alt boyutları ile psikolojik sözleşme ihlali arasındaki ilişkileri saptamak amacıyla korelasyon ve regresyon analizi yapılmıştır. Elde edilen veriler normal dağılıma sahiptir. Veri setinin analiz edilip yorumlanması için SPSS paket programı kullanılmıştır. 
Güvenilirlik analizine göre hesaplanan Cronbach's Alpha değerleri sosyal bilimler alanında 0.70'ten büyük olmalıdır (Yaşar, 2014, s.63). Tablo 1 'de araştırmada kullanılan ölçeklerin güvenilirlik analizi sonuçlarına yer verilmiştir.

Tablo 1: Araştırmada Kullanılan Ölçeklerin Güvenilirlik Analizleri

\begin{tabular}{llll}
\hline No & Alt Boyut & Madde & Cronbach's Alpha Değeri \\
\hline 1 & Örg. Sessizlik Ölçeği & $\mathbf{1 5}$ & $\mathbf{8 5 1}$ \\
\hline 2 & Kabullenici Sessizlik & 5 &, 842 \\
\hline 3 & Korunmacı Sessizlik & 5 &, 821 \\
\hline 4 & Korumacı Sessizlik & 5 &, 817 \\
\hline 5 & Tükenmişlik Ölçeği & $\mathbf{2 2}$ &, 865 \\
\hline 6 & Duygusal Tükenme & 9 &, 867 \\
\hline 7 & Duyarsızlaşma & 5 &, 767 \\
\hline 8 & Kişisel B. H.Azalma & 8 &, 782 \\
\hline 9 & Psk. Sözl. İhlali Ölçeği & $\mathbf{9}$ &, 873 \\
\hline
\end{tabular}

Örgütsel sessizlik ölçeğine ait cronbach's alpha değeri; $0,851^{\prime}$ dir. Alt boyutları olan kabullenici sessizlik 0,842; korunmacı sessizlik 0,821; korumacı sessizlik $0,817^{\prime}$ dir. Tükenmişlik ölçeğine ait cronbach's alpha değeri; 0,865'tir Alt boyutlarına ait değerler şu şekildedir; duygusal tükenme 0,867; duyarsızlaşma 0,797 ve kişisel başarı hissinde azalma 0,782' dir. Psikolojik sözleşme ihlali ölçeğinin cronbach alpha güvenilirlik katsayısı 0,873 olarak belirlenmiştir. Cronbach alpha değerlerinin bu şekilde çıkması ölçeklerin güvenilir bir ölçüm sağladığı sonucunu vermektedir.

Araştırmaya katılan çalışanların sosyo-demografik bilgileri şu şekildedir: \%31,4'ü kadın ( $\mathrm{n}=71), \% 68,6$ 's ise erkektir ( $\mathrm{n}=155) ; \% 52,2$ 'si be$\operatorname{kar}(\mathrm{n}=118), \% 47,8^{\prime} \mathrm{i}$ evlidir $(\mathrm{n}=108)$; çalışma şekli bakımından \%61,1'i vardiyasız (devamlı gündüz/gece) $(\mathrm{n}=138), \% 38,9^{\prime} \mathrm{u}$ vardiyalıdır $(\mathrm{n}=88)$; $\% 63,3$ 'ü 18-30 yaş aralığında (n=143), \%18,6'sı 31-43 yaş aralığında ( $n=42)$, $\% 18,1^{\prime}$ i ise 44 yaş ve üzeri $(n=41)$ yaş grubundadır; eğitim durumuna bakıldığında \%30,5'i ilköğretim mezunu (n=69), \%21,7'si lise mezunu $(\mathrm{n}=49), \% 28,3^{\prime}$ ü ön Lisans ( $\left.\mathrm{n}=64\right), \% 19,5^{\prime} \mathrm{i}$ lisans ve lisans üzeri mezunudur (44); katılımcıların çalışma süreleri \%45,6'sı 1-5 yıl arasında (n=103), \%23,5'i 6-10 yıl arasında (n=53), \%15,5'i 11-15 yıl arasında (n=35), \%15,5'i 15 yil ve üzeri $(n=35)$ toplam çalışma süresindedirler. 
Araştırma ağımsız değişken olan örgütsel sessizliğin alt boyutları olan kabullenici sessizlik, korunmacı sessizlik, korumacı sessizlik ve tükenmişliğin alt boyutları olan duygusal tükenme, duyarsızlaşma, kişisel başarı hissinde azalmanın psikolojik sözleşme ihlali değişkenleri arasındaki ilişkilerin yön ve büyüklüklerinin tespit edilmesine yönelik olarak korelasyon analizi yapılmıştır. $\mathrm{Bu}$ araştırma sonucunda elde edilen verilerin normal dağılmadıkları göz önüne alınarak Spearman Korelasyon Analizi uygulanmıştır. Analiz sonucunda elde edilen bulgular Tablo 2'de verilmiştir.

Tablo 2. Örgütsel Sessizlik ile Tükenmişliğin Alt Boyutlan ve Psikolojik Sözleşme İhlali Algısına İlişkin Korelasyon Analizi Sonuçlar

\begin{tabular}{|c|c|c|c|c|c|c|c|c|}
\hline & & $\begin{array}{l}\text { Kabul. } \\
\text { Sessizlik }\end{array}$ & $\begin{array}{l}\text { Korun. } \\
\text { Sessizlik }\end{array}$ & $\begin{array}{l}\text { Koru. } \\
\text { Sessizlik }\end{array}$ & $\begin{array}{l}\text { Duy. } \\
\text { Tük. }\end{array}$ & Duyarsızlaşma & $\begin{array}{l}\text { K.B.H. } \\
\text { Azalma }\end{array}$ & $\begin{array}{l}\text { Psk. } \\
\text { Sözl. } \\
\text { İhlali }\end{array}$ \\
\hline \multirow{3}{*}{$\begin{array}{l}\text { Kabul. } \\
\text { Sessizlik }\end{array}$} & K. & 1 & & & & & & \\
\hline & $P(p)$ & & & & & & & \\
\hline & $\mathrm{N}$ & 226 & & & & & & \\
\hline \multirow{3}{*}{$\begin{array}{l}\text { Korun. } \\
\text { Sessizlik }\end{array}$} & $\mathrm{K}$. & $0,670^{* *}$ & 1 & & & & & \\
\hline & $\mathrm{P}(\mathrm{p})$ & 0,000 & & & & & & \\
\hline & $\mathrm{N}$ & 226 & 226 & & & & & \\
\hline \multirow{3}{*}{$\begin{array}{l}\text { Koru. } \\
\text { Sessizlik }\end{array}$} & K. & $0,612^{* *}$ & $0,696^{* *}$ & 1 & & & & \\
\hline & $\overline{P(p)}$ & 0,000 & 0,000 & & & & & \\
\hline & $\mathrm{N}$ & 226 & 226 & 226 & & & & \\
\hline \multirow{3}{*}{ Duy. Tük. } & $\mathrm{K}$. & $0,609^{* *}$ & $0,643^{* *}$ & $0,729^{* *}$ & 1 & & & \\
\hline & $P(p)$ & 0,000 & 0,000 & 0,000 & & & & \\
\hline & $\mathrm{N}$ & 226 & 226 & 226 & 226 & & & \\
\hline \multirow{3}{*}{$\begin{array}{l}\text { Duyar } \\
\text { sizlaşma }\end{array}$} & K. & $0,923^{* *}$ & $0,619^{* *}$ & $0,649^{* *}$ & $0,619^{* *}$ & 1 & & \\
\hline & $\mathrm{P}(\mathrm{p})$ & 0,000 & 0,000 & 0,000 & 0,000 & & & \\
\hline & $\mathrm{N}$ & 226 & 226 & 226 & 226 & 226 & & \\
\hline \multirow{3}{*}{$\begin{array}{l}\text { K.B.H. } \\
\text { Azalma }\end{array}$} & K. & $0,810^{* *}$ & $0,875^{* *}$ & $0,765^{* *}$ & $0,742^{* *}$ & $0,800^{* *}$ & 1 & \\
\hline & $\mathrm{P}(\mathrm{p})$ & 0,000 & 0,000 & 0,000 & 0,000 & 0,000 & & \\
\hline & $\mathrm{N}$ & 226 & 226 & 226 & 226 & 226 & 226 & \\
\hline \multirow{3}{*}{$\begin{array}{l}\text { Psk. Söz. } \\
\text { İhlali }\end{array}$} & $\mathrm{K}$. & $0,878^{* *}$ & $0,904^{* *}$ & $0,706^{* *}$ & $0,651^{* *}$ & $0,806^{* *}$ & $0,882^{* *}$ & 1 \\
\hline & $\mathrm{P}(\mathrm{p})$ & 0,000 & 0,000 & 0,000 & 0,000 & 0,000 & 0,000 & \\
\hline & $\mathrm{N}$ & 226 & 226 & 226 & 226 & 226 & 226 & 226 \\
\hline
\end{tabular}

**Korelasyon 0,01 düzeyinde anlamlıdır, $\mathrm{n}=226$

Tablo 2 incelendiğinde, tüm değişkenler arasında \%99 önem düzeyinde anlamlı bir ilişki olduğu görülmektedir. Tablodaki değerlere göre kabullenici sessizlik alt boyutu ve psikolojik sözleşme ihlali arasında $\left(\mathrm{r}=0,878^{* *}\right)$; korunmacı sessizlik alt boyutu ve psikolojik sözleşme ihlali 
arasında $\left(\mathrm{r}=0,904^{* *}\right)$; korumacı sessizlik alt boyutu ve psikolojik sözleşme ihlali arasinda $\left(\mathrm{r}=0,706^{* *}\right)$; duygusal tükenme alt boyutu ve psikolojik sözleşme ihlali arasında $\left(\mathrm{r}=0,651^{* *}\right)$; duyarsılaşma alt boyutu ve psikolojik sözleşme ihlali arasında $\left(\mathrm{r}=0,806^{* *}\right)$; kişisel başarı hissinde azalma alt boyutu ve psikolojik sözleşme ihlali arasında $\left(\mathrm{r}=0,882^{* *}\right)$ pozitif ve kuvvetli bir ilişki bulunmaktadır. Bu sonuçlardan hareketle, çalışanların örgütsel sessizliği ve tükenmişlikleri arttığında psikolojik sözleşme ihlali artacağ1 söylenebilir.

Tablo 3. Örgütsel Sessizlik ile Tükenmişliğin Alt Boyutlarn ve Psikolojik Sözleşme İhlali Algısına İlişkin Regresyon Analizi Sonuçları

\begin{tabular}{llllll}
\hline \multirow{2}{*}{ Model } & \multicolumn{5}{c}{ Psikolojik Sözleşme İhlali Alg1sı } \\
\cline { 2 - 6 } & $\mathbf{B}$ & Stn. Hata & $\mathbf{B}$ & $\mathbf{T}$ & $\mathbf{p}$ \\
\hline Kabullenici Sessizlik & 0,860 & 0,063 & 0,551 & 13,743 & 0,000 \\
\hline Korunmacı Sessizlik & 1,118 & 0,054 & 0,646 & 20,551 & 0,000 \\
\hline Korumacı Sessizlik & 0,098 & 0,044 & 0,055 & 2,252 & 0,025 \\
\hline Duygusal Tükenme & $-0,031$ & 0,024 & $-0,030$ & $-1,292$ & 0,198 \\
\hline Duyarsılaşma & $-0,004$ & 0,068 & $-0,003$ & $-0,066$ & 0,947 \\
\hline $\begin{array}{l}\text { Kişisel Başarı } \\
\text { Hissinde Azalma }\end{array}$ & $-0,189$ & 0,056 & $-0,148$ & $-3,375$ & 0,001 \\
\hline \multicolumn{1}{c}{$\mathrm{R}=0,977$} & $\mathrm{R}^{2}=, 955$ & Durbin-Watson=s1,802 & $\mathrm{F}=775,991$ & $\mathrm{p}=0,000$ \\
\hline
\end{tabular}

Sonuçlara göre, çoklu regresyon modelinin anlamlı olduğu ( $\mathrm{F}=775,991$; $\mathrm{p}<0,000)$ ve belirlilik katsayısına $\left(\mathrm{R}^{2}=0,955\right)$ göre bağımlı değişkenin \%95,5'inin bağımsız değişkenler tarafından açılanabildiği tespit edilmiştir. Değişkenler incelendiğinde örgütsel sessizliğin alt boyutlarının psikolojik sözleşme ihlali ile doğru yönlü bir ilişkiye sahip olduğu tespit edilmiştir. Bulgular neticesinde H1, (kabullenici sessizlik psikolojik sözleşme ihlali üzerinde istatistiki olarak anlamlı bir etkiye sahiptir) $\mathrm{H} 2$ (korunmacı sessizlik psikolojik sözleşme ihlali üzerinde istatistiki olarak anlamlı bir etkiye sahiptir) ve H3 (korumacı sessizlik psikolojik sözleşme ihlali üzerinde istatistiki olarak anlamlı bir etkiye sahiptir) hipotezleri kabul edilmektedir. H4 (duygusal tükenme psikolojik sözleşme ihlali üzerinde istatistiki olarak anlamlı bir etkiye sahiptir) ve H5 (duyarsızlaşma psikolojik sözleşme ihlali üzerinde istatistiki olarak anlamlı bir etkiye sahiptir) hipotezleri red edilmektedir. H6 (kişisel başarı hissinde azalma psikolojik sözleşme ihlali üzerinde istatistiki olarak anlamlı bir etkiye sahiptir) hipotezi kabul edilmektedir. Örgütsel sessizlik ve alt 
boyutları arttığında psikolojik sözleşme ihlali artmaktadır. Tükenmişliğin alt boyutlarından duygusal tükenme ve duyarsızlaşma ile psikolojik sözleşme arasında anlamlı bir ilişki yoktur.

Yapılan varyans analizlerine göre bazı demografik faktörler ile katılımcların örgütsel sessizlik, tükenmişlik ve psikolojik sözleşme ihlali arasında anlamlı farklılıklar tespit edilmiştir.

Grup istatistiklerine bakıldığında yapılan analizlerde;

Yaş ile örgütsel sessizlik, tükenmişlik ve psikolojik sözleşme ihlali arasında ilk olarak homojenliğe bakılması gerekmektedir. Tablo 4'te homojenlik testi sonuçları verilmektedir.

Tablo 4: Yaş ve Değişkenlere İlişkin Homojenlik Testi

Test of Homogeneity of Variances

\begin{tabular}{lllll}
\hline & Levene Statistic & df1 & df2 & $p$ \\
\hline Psikolojik Sözleşme İhlali & 2,653 & 2 & 223 &, 073 \\
\hline Örgütsel Sessizlik & 1,154 & 2 & 223 &, 317 \\
\hline Tükenmişlik & 1,594 & 2 & 223 &, 205 \\
\hline
\end{tabular}

Tablo 4'e göre p değerleri 0,05'ten büyük olduğu için homojen olduğunu söylemek mümkündür ve Anova analizi sonuçlarına bakılmalıdır.

Tablo 5. Katılımcıların Yaşları ile Örgütsel Sessizlik, Tükenmişlik ve Psikolojik Sözleşme İhlaline İlişkin Anova Sonuçlarn

\begin{tabular}{|c|c|c|c|c|}
\hline Değişken & Yaş & Ortalama $(\overline{\mathbf{X}})$ & F değeri & $P(p)$ \\
\hline \multirow{3}{*}{ Örgütsel Sessizlik } & $18-30$ & 30,1119 & \multirow{3}{*}{4,330} & \multirow{3}{*}{0,014} \\
\hline & $31-43$ & 26,2143 & & \\
\hline & 44 ve üzeri & 29,3659 & & \\
\hline \multirow{3}{*}{ Tükenmişlik } & $18-30$ & 49,7273 & \multirow{3}{*}{5,374} & \multirow{3}{*}{0,005} \\
\hline & $31-43$ & 42,9524 & & \\
\hline & 44 ve üzeri & 47,9756 & & \\
\hline \multirow{3}{*}{ Psk. Sözleşme İhlali } & $18-30$ & 74,4476 & \multirow{3}{*}{7,800} & \multirow{3}{*}{0,001} \\
\hline & $31-43$ & 63,5476 & & \\
\hline & 44 ve üzeri & 72,1463 & & \\
\hline
\end{tabular}

Tablo 5'te çalışanların yaşları ile örgütsel sessizlik, tükenmişlik ve psikolojik sözleşme ihlaline ilişkin Anova analizi sonuçları verilmiştir. Bu sonuçlar incelendiğinde; yaş ile tüm değişkenler arasında anlamlı bir ilişki görülmektedir $(\mathrm{p}<0,05)$. Farklılığın hangi gruptan kaynaklandığını anlamak için tukey testi sonuçlarına bakılmalıdır. 
Tablo 6: Yaş ile Örgütsel Sessizlik Arasındaki Tukey Testi

Örgütsel Sessizlik

Tukey HSD a,b

\begin{tabular}{llll}
\hline & & \multicolumn{2}{l}{ Subset for alpha $=0.05$} \\
\cline { 2 - 3 } Yaş & $\mathbf{N}$ & $\mathbf{1}$ & $\mathbf{2}$ \\
\hline $31-43$ & 42 & 42,9524 & \\
\hline 44 ve üzeri & 41 & 47,9756 & 47,9756 \\
\hline $18-30$ & 143 & & 49,7273 \\
\hline $\mathbf{p}$ & &, 070 &, 719 \\
\hline
\end{tabular}

Genç yaş grubunda bulunan çalışanların örgütsel sessizlikleri en üst seviyededir. Örgütsel sessizlikleri en düşük olan grup ise 31-43 yaş grubunda olanlardır. Genç yaş grubundaki işgörenlerin çalışmaya yeni başladıkları varsayılarak henüz kurumu ve çalışma ortamını tanımadıklarından örgüt içinde sessiz kaldıkları söylenebilir.

Tablo 7: Yaş ile Tükenmişlik Arasındaki Tukey Testi

Tükenmişlik

Tukey HSD ${ }^{\mathrm{a}, \mathrm{b}}$

\begin{tabular}{llll}
\hline & & \multicolumn{2}{l}{ Subset for alpha $=0.05$} \\
\cline { 2 - 3 } Yaş & $\mathrm{N}$ & 1 & 2 \\
\hline $31-43$ & 42 & 63,5476 & \\
\hline 44 ve üzeri & 41 & & 72,1463 \\
\hline $18-30$ & 143 & 1,000 & 74,4476 \\
\hline $\mathrm{p}$ & &, 726 \\
\hline
\end{tabular}

Tükenmişlik seviyesi en yüksek olan grup 18-30 yaş grubu iken tükenmişliği en düşük olan yaş grubu 31-43 yaş grubundakilerdir. Genç yaş grubundaki işgörenler çalışma hayatının zorlukları ile yani tanıştıklarından ve henüz çalışma temposuna alışamadıklarından tükenmişlik seviyeleri daha fazladır.

Tablo 8: Yaş ile Psikolojik Sözleşme İhlali Arasındaki Tukey Testi

\begin{tabular}{|c|c|c|c|}
\hline \multicolumn{4}{|c|}{ Psikolojik Sözleşme İhlali } \\
\hline \multicolumn{4}{|c|}{ Tukey HSDa,b } \\
\hline \multirow[b]{2}{*}{ Yaş } & \multirow[b]{2}{*}{$\mathbf{N}$} & \multicolumn{2}{|c|}{ Subset for alpha $=0.05$} \\
\hline & & 1 & 2 \\
\hline $31-43$ & 42 & 26,2143 & \\
\hline 44 ve üzeri & 41 & 29,3659 & 29,3659 \\
\hline $18-30$ & 143 & & 30,1119 \\
\hline $\mathrm{p}$ & & ,078 & 8,864 \\
\hline
\end{tabular}


Genç yaş grubunda bulunan çalışanların psikolojik sözleşme ihlalleri en üst seviyededir. Psikolojik sözleşme ihlalinin en düşük olduğu grup 31-43 yaş grubunda olanlardır.

Tablo 9: Yaş ve Değişkenlere İlişkin Homojenlik Testi

\begin{tabular}{llllc}
\hline \multicolumn{1}{l}{ Test of Homogeneity of Variances } & Levene Statistic & $\mathrm{df1}$ & $\mathrm{df2}$ & $\mathrm{p}$ \\
\hline Psikolojik Sözleşme İhlali & 1,426 & 3 & 222 &, 236 \\
\hline Örgütsel Sessizlik &, 890 & 3 & 222 &, 447 \\
\hline Tükenmişlik &, 534 & 3 & 222 &, 659 \\
\hline
\end{tabular}

Tablo 9'a göre p değerleri 0,05'ten büyük olduğu için veriler homojen dağılım göstermektedir ve ve Anova analizi sonuçlarına bakılmalıdır.

Tablo 10. Katılımcıların Ĕ̆itimleri ile Örgütsel Sessizlik, Tükenmişlik ve Psikolojik Sözleşme İhlaline İlişkin Anova Sonuçları

\begin{tabular}{|c|c|c|c|c|}
\hline Değişken & Eğitim & Ortalama $(\overline{\mathbf{X}})$ & F değeri & $P(p)$ \\
\hline \multirow{4}{*}{ Örgütsel Sessizlik } & İlköğretim & 14,4951 & \multirow{4}{*}{3,600} & \multirow{4}{*}{0,014} \\
\hline & Lise & 16,0133 & & \\
\hline & Ön Lisans & 15,8765 & & \\
\hline & Lisans & 15,7273 & & \\
\hline \multirow{4}{*}{ Tükenmişlik } & İlköğretim & 12,4757 & \multirow{4}{*}{3,769} & \multirow{4}{*}{0,011} \\
\hline & Lise & 13,2667 & & \\
\hline & Ön Lisans & 13,1358 & & \\
\hline & Lisans & 13,3636 & & \\
\hline \multirow{4}{*}{ Psk. Sözleşme İhlali } & İlköğretim & 6,6311 & \multirow{4}{*}{1,997} & \multirow{4}{*}{0,115} \\
\hline & Lise & 6,9733 & & \\
\hline & Ön Lisans & 6,9630 & & \\
\hline & Lisans & 7,3273 & & \\
\hline
\end{tabular}

Tablo 10 'da çalışanların eğitimleri ile örgütsel sessizlik, tükenmişlik ve psikolojik sözleşme ihlaline ilişkin Anova analizi sonuçları verilmiştir. Bu sonuçlar incelendiğinde; eğitim ile örgütsel sessizlik ve tükenmişlik arasında anlamlı bir ilişki görülmektedir $(\mathrm{p}<0,05)$. Farklılığın hangi gruptan kaynaklandığını anlamak için tukey testi sonuçlarına bakılmalıdır. Eğitim ile psikolojik sözleşme ihlali arasında ise anlamlı bir ilişki bulunmamaktadir. 
Tablo 11: Yaş ile Örgütsel Sessizlik Arasındaki Tukey Testi

Örgütsel Sessizlik

Tukey HSD a,b

\begin{tabular}{llll}
\hline & & \multicolumn{2}{l}{ Subset for alpha $=0.05$} \\
\cline { 3 - 4 } Eğitim & $\mathbf{N}$ & $\mathbf{1}$ & $\mathbf{2}$ \\
\hline Ilköğretim & 69 & 44,3768 & \\
\hline Lisans & 44 & 48,8636 & 48,8636 \\
\hline Lise & 49 & 49,5306 & 49,5306 \\
\hline Ön Lisans & 64 & & 50,6719 \\
\hline $\mathrm{P}$ & &, 106 &, 854 \\
\hline
\end{tabular}

Tablo 11'e göre örgütsel sessizliği en yüksek olan grup ön lisans eğitimi almış olanlardır. Örgütsel sessizliği en düşük olan grup ise ilköğretim eğitimi almış olan çalışanlardır.

Tablo 12: Eğitim ile Tükenmişlik Arasındaki Tukey Testi

\begin{tabular}{llll}
\hline Tükenmişlik & & \\
\hline Tukey HSD & & \\
\hline Eğb & & Subset for alpha $=0.05$ & \\
\hline İitim & $\mathbf{N}$ & $\mathbf{1}$ & $\mathbf{2}$ \\
\hline Lise & 69 & 66,7391 & 73,4694 \\
\hline Lisans & 49 & 73,4694 & 73,8409 \\
\hline Önlisans & 44 & 73,8409 & 75,2969 \\
\hline p & 64 & &, 932 \\
\hline
\end{tabular}

Tablo 12 incelendiğinde tükenmişliği en yüksek olan grubun ön lisans eğitimi almış olanlar olduğu, tükenmişliği en düşük olan grup ise ilköğretim eğitimi almış olanlar olduğu görülmektedir.

Tablo 13: Çalışma Süresi ve Değişkenlere İlişkin Homojenlik Testi

\begin{tabular}{|c|c|c|c|c|c|}
\hline \multicolumn{6}{|c|}{ Test of Homogeneity of Variances } \\
\hline & Levene Statistic & & df1 & df2 & $\mathrm{p}$ \\
\hline Psikolojik Sözleşme İhlali & 1,664 & 3 & & 222 & ,176 \\
\hline Örgütsel Sessizlik & 1,149 & 3 & & 222 & ,330 \\
\hline Tükenmişlik & 711 & 3 & & 222 & ,546 \\
\hline
\end{tabular}

Tablo 13'e göre p değerleri 0,05'ten büyük olduğu için veriler homojen dağılım göstermektedir ve Anova analizi sonuçlarına bakılmalıdır. 
Tablo 14. Katılımcıların Çalışma Süreleri ile Örgütsel Sessizlik, Tükenmişlik ve Psikolojik Sözleşme İhlaline İlişkin Anova Sonuçları

\begin{tabular}{|c|c|c|c|c|}
\hline Değişken & Çalışma Süresi & Ortalama $(\overline{\mathbf{X}})$ & F değeri & $P(p)$ \\
\hline \multirow{4}{*}{ Örgütsel Sessizlik } & $1-5 y_{11}$ & 46,7476 & \multirow{4}{*}{4,111} & \multirow{4}{*}{0,007} \\
\hline & 6-10yıl & 52,5283 & & \\
\hline & 11-15yıl & 49,2286 & & \\
\hline & $15 y ı l$ ve üzeri & 44,5714 & & \\
\hline \multirow{4}{*}{ Tükenmişlik } & $1-5 y \mathrm{ll}$ & 70,2718 & \multirow{4}{*}{3,215} & \multirow{4}{*}{0,024} \\
\hline & 6-10yıl & 77,3396 & & \\
\hline & 11-15yıl & 73,1429 & & \\
\hline & $15 y$ yl ve üzeri & 67,8857 & & \\
\hline \multirow{4}{*}{ Psk. Sözleşme İhlali } & $1-5 y \mathrm{ll}$ & 28,4175 & \multirow{4}{*}{5,174} & \multirow{4}{*}{0,002} \\
\hline & $6-10 y_{1} l$ & 32,4528 & & \\
\hline & 11-15yıl & 29,5143 & & \\
\hline & $15 y ı l$ ve üzeri & 26,6000 & & \\
\hline
\end{tabular}

Tablo 14' te katılımcıların çalışma süreleri ile örgütsel sessizlik, tükenmişlik ve psikolojik sözleşme ihlaline ilişkin Anova analizi sonuçları verilmiştir.

Tablo 15: Çalışma Süresi ile Örgütsel Sessizlik Arasındaki Tukey Testi

\begin{tabular}{|c|c|c|c|}
\hline \multicolumn{4}{|c|}{ Örgütsel Sessizlik } \\
\hline \multicolumn{4}{|c|}{ Tukey HSDa,b } \\
\hline \multirow[b]{2}{*}{ Çalışma Süresi } & \multirow[b]{2}{*}{$\mathbf{N}$} & \multicolumn{2}{|c|}{ Subset for alpha $=0.05$} \\
\hline & & 1 & 2 \\
\hline 15yıl ve üzeri & 35 & 44,5714 & \\
\hline $1-5 y_{1} 1$ & 103 & 46,7476 & 46,7476 \\
\hline 11-15yıl & 35 & 49,2286 & 49,2286 \\
\hline 6-10yıl & 53 & & 52,5283 \\
\hline $\mathrm{p}$ & & 226 & ,085 \\
\hline
\end{tabular}

Tablo 15'e göre örgütsel sessizliğin en yüksek olduğu grup mevcut işletmede 6-10yıl arasındaki çalışanlardır. Örgütsel sessizliği en düşük olan grup ise mevcut işletmede 15 yıl ve üzerinde çalışmakta olanlardır.

Tablo 16: Çalışma Süresi ile Tükenmişlik Arasındaki Tukey Testi

\begin{tabular}{|c|c|c|c|}
\hline \multicolumn{4}{|l|}{ Tükenmişlik } \\
\hline \multicolumn{4}{|l|}{ Tukey HSDa,b } \\
\hline \multirow[b]{2}{*}{ Çalışma Süresi } & \multirow[b]{2}{*}{$\mathrm{N}$} & \multicolumn{2}{|c|}{ Subset for alpha $=0.05$} \\
\hline & & 1 & 2 \\
\hline 15 yıl ve üzeri & 35 & 67,8857 & \\
\hline $1-5 y 11$ & 103 & 70,2718 & 70,2718 \\
\hline 11-15y1l & 35 & 73,1429 & 73,1429 \\
\hline $6-10 y 11$ & 53 & & 77,3396 \\
\hline p & & ,386 & ,144 \\
\hline
\end{tabular}


Tablo 16'ya göre tükenmişliği en yüksek olduğu grup mevcut işletmede 6-10yıl arasındaki çalışanlardır. Tükenmişliği en düşük olan grup ise mevcut işletmede 15 yıl ve üzerinde çalışmakta olanlardır.

Tablo 17: Çalışma Süresi ile Psikolojik Sözleşme İhlali Arasındaki Tukey Testi

\begin{tabular}{llll}
\hline Psikolojik Sözleşme İhlali & & \\
\hline Tukey HSD & & \\
\hline Çalışma Süresi & $\mathbf{N}$ & \multicolumn{2}{l}{ Subset for alpha $=0.05$} \\
\hline 15yıl ve üzeri & 35 & $\mathbf{1}$ & $\mathbf{2}$ \\
\hline 1-5yıl & 103 & 26,6000 & \\
\hline 11-15yıl & 35 & 28,4175 & 29,5143 \\
\hline 6-10yıl & 53 & 29,5143 & 32,4528 \\
\hline $\mathbf{p}$ & & &, 230 \\
\hline
\end{tabular}

Tablo 17'ye göre psikolojik sözleşme ihlali en yüksek olan grup mevcut işletmede 6-10 yıl arasındaki çalışanlardır. Psikolojik sözleşme ihlalinin en düşük olduğu grup ise mevcut işletmede 15 yıl ve üzerinde çalışmakta olanlardır.

\section{Tartışma ve Sonuç}

Yapılan araştırma sonuçlarına göre; çalışanların örgütsel sessizliği ve tükenmişlikleri arttığında psikolojik sözleşme ihlali artacağı belirlenmiştir. Ayrıca örgütsel sessizliğin alt boyutlarının psikolojik sözleşme ihlali ile doğru yönlü bir ilişkiye sahip olduğu tespit edilmiştir. Bulgular neticesinde kabullenici sessizlik, korumacı sessizlik ve korunmacı sessizlik psikolojik sözleşme ihlali üzerinde pozitif yönlü kuvvetli bir etkiye sahiptir. Tükenmişliğin alt boyutu olan kişisel başarı hissinde azalma ile psikolojik sözleşme ihlali arasında ters yönlü bir ilişki bulunmaktadır. Kişisel başarı hissinde azalma yaşandıkça psikolojik sözleşme ihlalini artmaktadir.

Mevcut çalışmanın diğer sonuçlarına göre; genç yaş grubu olan 18-30 yaş aralığındaki işgörenlerin örgütsel sessizlikleri, tükenmişlikleri ve psikolojik sözleşme ihlalleri en üst seviyede iken 31-43 yaş grubunda olanların en düşük seviyededir. Örgütsel sessizliği ve tükenmişliği en yüksek 
olan grup ön lisans eğitimi almış olanlar iken örgütsel sessizliği ve tükenmişliği en düşük olan grup ise ilköğretim eğitimi almış olan işgörenlerdir. Çalışma süresi bakımından örgütsel sessizlik, tükenmişlik ve psikolojik sözleşme ihlallerinin en üst seviyede olduğu grup 6-10 yıl arasındaki çalışanlar iken en düşük olan grup 15 yıl ve üzerinde çalışmakta olanlardır. $\mathrm{Bu}$ sonuçlara göre çalışma hayatına yeni başlayan işgörenlerde kurum kültürüne henüz adapte olamamaları, iş yaşantısının temposuna alışılamaması gibi sebeplerden dolayı örgütsel sessizlik, tükenmilki ve psikolojik sözleşme ihlali daha fazladır.

Örgüt ortamında çalışanların üst yöneticilere karşı açık olabildikleri iletişim yapısını kurmaları, yöneticilerin bu ortama destek vermeleri ile örgüt içerisindeki sessizliği, çok sesliliğe; tükenmişliği yaşam doyumu ve iş tatminine çevirebilmek için bir firsat oluşturabilir. Kurum içinde var olan problemlerin yöneticilere yansitılmasını sağlayan ciddi kanalların var oluşu, bu kanalları kullanması beklenenlerde adalet algısı ve memnun olma düzeylerinde olumlu karşılıklar bulacaktır. Böylece yüksek düzeyde güven duyan işgörenlerin tükenmişlik ve sessizlik eğilimlerini azaltacak ve fikirlerini rahatça, net biçimde ifade edebilmeleri sağlanacaktır.

Örgütsel sessizliğin, tükenmişliğin ve psikolojik sözleşme ihlalinin giderilmesi için yönetimin, personelin genel motivasyon seviyesini arttırması için çalışan personeli motive etmenin önemini anlaması gerekmektedir. Bu içerikte, üst düzeydeki karar vericiler, personel motivasyonunu mümkün kılan ve destekleyen bir organizasyon yapısı belirlemelidir. Bundan sonra, organizasyon yapısı uygun motivasyon politikasını tanımlamalıdır. En iyi motivasyonu seçmek politikaları, personelin özelliklerini, becerilerini ve ihtiyaçlarını analiz etmek için hayati öneme sahiptir (Çetin, 2012, s.78).

Bireyleri motive etmek için kullanılan araçlar, kişisel değer yargıları, çevresel faktörler ve sosyal eğitim durumundaki farklılıklar nedeniyle kişiden kişiye farklı etkiye sahip olabilir.

Çalışmamızın bir takım sınırlılıkları da bulunmaktadır. Çalışma tek bir ilde gerçekleştirilmiştir. Dolayısıyla, özel bir coğrafi bölgede veya farklı sektörlerde yapılacak çalışmalar ile bazı farklılıklar göstermesi mümkündür. Bununla birlikte, daha geniş bir örneklem ile gerçekleştirilecek çalışmalar, sonuçların genellenebilirliği arttıracaktır. 
$\mathrm{Bu}$ konuda araştırma yapmak isteyen diğer araştırmacılara da bazı öneriler sunulabilir; örgütsel sessizlik ve tükenmişlik değişkenlerinin psikolojik sözleşme ihlalinin alt boyutlarıyla arasındaki ilişki incelenebilir. Bunun yanında psikolojik sözleşme ihlalini azaltabileceği düşünülen örgütsel destek, örgütsel vatandaşlık, liderlik tutumları, örgütsel güven, personel güçlendirme gibi konularla ilişkisi üzerine çalışmalar yapılarak bu ilişkilerin ülkesel bazda değişiklik gösterip göstermediği kıyaslamalı olarak araştırılabilir. 


\section{EXTENDED ABSTRACT}

\section{A Research on the Effects of Organizational Silence and Burnout on Psychological Contract Violation}

Fatma Yilmaz

Erzincan Binali Yıldırımı University

In this study, the relationship between organizational silence, burnout and psychological contract violation was examined. In this study, it is aimed whether the silence and burnout of the employees in the enterprise cause psychological contract violations. Accordingly, in the first part of the study, a literature review was conducted to explain the organizational silence, burnout and psychological contract violations.

In the modern economic world where competition conditions become difficult and the borders become more uncertain due to globalization, it is expected that the employees' freedom of expression increases, their creativity increases and they have more responsibility awareness (Quinn and Spreitzer, 1997, p.36). Today, one of the biggest goals of enterprises is to continuously improve their employees' knowledge, skills and abilities and to reach the most accurate information required for the organization. However, different behaviors emerge as a result of the relationships among the employees within the organization. In this process, employees can establish close relations with each other, and they may move away from each other. However, in order to reach the predetermined goals within the organization, it is very important to develop relations and communication among the employees in the organization. On the other hand, it is known that employees do not always communicate well, avoid or exhibit distant behaviors towards other employees (Demir and Demir, 2012, p.85). This situation can cause situations such as employee silence and burnout.

The concept of organizational silence; It is explained that the employee avoids sharing his / her emotional, behavioral and mental discourses regarding the current situation of the company he / she is a member of (Pinder ve Harlos, 2001, p.334). Organizational silence is defined as the fact that employees do not react jointly and intentionally and share their feelings and 
thoughts with others (Ülker and Kanter, 2009, p.111). Organizational silence, employees' workplace or work related to behavioral problems or technical problems about their opinions, thoughts and knowledge of the conscious way to remain silent by not passing to them (Çakıc1, 2010, p.91).

Another negative situation that may arise in employees is burnout. The concept of burnout is that individuals move away from the essence of their work as a profession and do not care about the people they serve, or withdraw themselves from their jobs and cool down in response to dissatisfaction and excessive stress (Kaçmaz, 2005, p.29; Çetin, 2017, p.84-85). Freudenberger burnout; "Failure, attrition, energy and power reduction or as a result of unsatisfied desires as a result of the individual's internal state of exhaustion tanim (Freudenberger, 1974, p.159). Maslach and Jackson (1981) burnout; It is defined as a syndrome that involves emotional exhaustion, depersonalization and decrease in personal success to which individuals are requested.

In the emotional exhaustion dimension, the individual shows symptoms such as fatigue, energy loss and emotional exhaustion. This dimension is seen as the internal dimension of burnout. Emotional burnout employees feel that they do not behave as responsibly towards the people they serve, however the necessity to go to the same job in individuals with disability and stress causes anxiety (Maslach et al., 2001). Emotional exhaustion is simply expressed as, exhaustion of emotional resources en (Akın and Oğuz, 2010, p.314). Emotional exhaustion; The most important element of burnout is its beginning and focus. This item is more relevant to work-induced tension. Working at a cramped pace, the individual is emotionally exhausted and feels crushed by the demands of others. Burnout is experienced as a reaction against these conditions (Üngüren et al., 2010, p.2924).

In this study, it is aimed whether the silence and burnout of the employees in the enterprise cause psychological contract violations. In this direction, whether the sub-dimensions of organizational silence, acceptive silence, protective silence, protective silence and emotional exhaustion and depersonalization, which are the sub-dimensions of burnout, affect the violation of psychological contract.

In the second part, the effects of organizational silence and burnout on psychological contract violations and the relationship between variables and demographic data are explained. Correlation, regression and Anova analyzes 
were performed. The sample of the study consists of 226 employees working in a production enterprise. The sampling method is easily sampled. Survey method was used as data collection method. The questionnaire was distributed to employees in February 2019. Of the 400 questionnaires distributed, 241 were collected. After the incorrectly filled out of these, 226 questionnaire results were used as data. The rate of return of the surveys is 56.5 .

Cronbach's alpha value of organizational silence scale; It is 0.851 . Acceptable silence with sub-dimensions was 0.842 ; protective silence 0.821 ; protective silence is 0.817 . Cronbach's alpha value of burnout scale; The values of the sub-dimensions are as follows; emotional exhaustion 0.867 ; desensitization is 0.797 and personal accomplishment is reduced to 0.782 . The cronbach's alpha reliability coefficient of the psychological contract violation scale was found to be 0.873 . According to the results of the research; It was determined that psychological contract violation would increase when the organizational silence and burnout of employees increased. In addition, it was found that the sub-dimensions of organizational silence had a correct relationship with psychological contract violation. As a result, accepting silence, protective silence and protective silence have a positive positive effect on the violation of psychological contract. There is an inverse relationship between the decrease in the sense of personal accomplishment, which is the sub-dimension of burnout, and the violation of psychological contract. As a decrease in the sense of personal success is experienced, the violation of psychological contract increases.

According to the other results of the present study; While the organizational silence, burnout and psychological contract violations of the employees between the ages of 18-30 are at the highest level in the young age group, it is at the lowest level of the ones in the age group of 31-43. While the group with the highest organizational silence and burnout was the ones who had associate degree education, the group with the lowest organizational silence and burnout was the employees who had primary education. In terms of working time, the group with the highest levels of organizational silence, burnout, and psychological contract violations were those who worked between 6-10 years, and the lowest group was those who worked for 15 years and over. According to these results, organizational silence, burnout and violation of psychological contract are more common in new employees due to reasons such as 
not being able to adapt to corporate culture and not getting used to the pace of work life.

\section{Kaynakça / References}

Akın, U., ve Oğuz, E. (2010). Öğretmenlerin işkoliklik ve tükenmişlik düzeylerinin ilişkisi ve çeşitli değişkenler açısından incelenmesi. Kuram ve Uygulamada Ĕ̆itim Yönetimi, 16(3), 309-327.

Anderson, N. ve Schalk, R. (1998). The psychological contract in retrospect and prospect. Journal of Organizational Behavior, 19, 637-647.

Bal, P. M., Lange, A. H. D., Jansen, P. G.W., Velde, M. E.G., ve Van D., (2008). Psychological contract breach and job attitudes: A meta-analysis of age as a moderator. Journal of Vocational Behavior, 72, 143-158.

Basım, H. N. ve Şeşen, H., (2006). Örgütsel vatandaşlık davranışı ölçeği uyarlama ve karşılaştırma çalışması. Ankara Üniversitesi SBF Dergisi, 61 (4), 1-20.

Civelek, M. E., Asci, M. S., ve Çemberci, M. (2015). Identifying silence climate in organizations in the framework of contemporary management approaches. International Journal of Research in Business and Social Science, 4(4), 36.

Coyle-Shapiro, J., ve Kessler, I. (2000). Consequences of the psychological contract for the employment relationship: A large scale survey. Journal of management studies, 37(7), 903-930.

Çakıcı, A. (2010). Örgütlerde işgören sessizliği, neden sessiz kalmayı tercih ediyoruz? Ankara: Detay Yayıncilik.

Çetin, I. (2012). Motivation and its impact on labour productivity at hotel business "a conceptual study". International Journal of New Trends in Arts, Sports E Science Education (IJTASE), 2(1), 70-79.

Çetin, İ. (2017). Otel çalışanlarında tükenmişlik ve tükenmişliğe etki eden faktörler. Balkan ve Yakın Doğu Sosyal Bilimler Dergisi, 3(2), 83-95.

Çimen, M., ve Ergin, C. (2001). Türk silahlı kuvvetleri sağlık personelinin tükenmişlik düzeylerinin incelenmesi. Gülhane Tıp Dergisi, 43(2), 169-176.

Demir, M., ve Demir, Ş. Ş. (2012). Yükseköğretim kurumlarında örgütsel sessizlik: Turizm lisans eğitimi kurumları örneği. Milli Ĕ̆itim Dergisi, 42(193), 184- 199. 
Demirci, B. (2018). The effects of stress on performance and burnout: A study of information technologies workers. Master's Thesis, Bahçeşehir University, İstanbul.

Dolunay, A. B. (2002). Keçiören ilçesi genel liseler ve teknik-ticaret-meslek liselerinde görevli öğretmenlerde tükenmişlik durumu araştırması, Ankara Üniversitesi Tip Fakültesi Mecmuası, 55(1), 51-62.

Dyne, V. L., Ang, S., ve Botero, I. C. (2003). Conceptualizing employee and employee voice as multidimensional constructs. Journal of Management Studies, 40(6), 1359-1392

Ehtiyar, R., ve Yanardağ, M. (2008). Organizational silence: A survey onemployees working in a chain hotel. Tourism and Hospitality Management, 14(1), 51-68.

Freudenberger, H. J. (1974). Staff burn-out. Journal of Social Issues, 30(1), 159-165.

Hartmann, N. N. (2012). Willingness to mentor: an examination of salesperson antecedents. Doktora Tezi, Purdue University, West Lafayette.

İraz, R., ve Ganiyusufoğlu, A. (2011). Örgütlerde mesleki tükenmişlik ve akademisyenler üzerinde bir uygulama. SÜ İ̈BF Sosyal ve Ekonomik Araştırmalar Dergisi, 11(21), 451-472.

Kaçmaz, N. (2005). Tükenmişlik (burnout) sendromu. İstanbul Tıp Fakültesi Dergisi, 68(1), 29-32.

Liao-Troth, M. A. (1999). The psychological contract of volunteer workers and its consequences. Doktora Tezi, The University of Arizona, Arizona.

Luthans, F., Youssef C., ve Avolio, B. (2007). Psychological capital. New York: Oxford University Press.

Maslach, C., Schaufeli, W. B.,ve Leiter, M. B. (2001). Job bournout. Annu. Rev. Psychol. 52, 397-422.

Maslach, C., ve Jackson, S. E. (1981). The measurement of experienced burnout. Journal of Organizational Behavior, 2(2), 99-113.

Maslach, C., ve Jackson, S. E. (1981). The measurement of experienced burnout. Journal of Occupational Behaviour, 2, 99-113.

Pinder C.C.ve Harlos K.P. (2001). Employee Silence: Quiescence and Acquiescence As Responses to Perceived Injustice, Research in Personnel and Human Resources Management, 20, 331-369.

Quinn, R. E., ve Spreitzer, G. M. (1997). The road to empowerment: Seven questions every leader should consider. Organizational Dynamics, 26(2), 37-49. 
Robinson, S. L., ve Rousseau, D.M. (1994). Violating the psychological contract: Not the exception but the norm. Journal of Organizational Behavior, 15, 245- 259

Rousseau, D. M. (1989). Psychological and implied contracts in organizations, Employee Responsibilities and Rights Journal, 2(2), 121-139.

Taşkıran, E. (2011). Liderlik ve örgütsel sessizlik arasındaki etkileşim. İstanbul: Beta Yayınevi.

Tükeltürk, Ş., Şahin Perçin, N. ve Güzel, B. (2012). Psikolojik kontrat ihlal algısı ile örgütsel bağlılık ilişkisi: otel işletmeleri üzerine bir araştırma. Yönetim Bilimleri Dergisi, 10(20), 93-110.

Tyagi, A., ve Agrawal, R. K. (2010). Emerging employment relationships: issues and concerns in psychological contract, The Indian Journal of Industrial Relations, 45 (3), 381-395.

Ülker, F., ve Kanten, P. (2009). Örgütlerde sessizlik iklimi, işgören sessizliği ve örgütsel bağlılık ilişkisine yönelik bir araştırma. Aksaray Üniversitesi İktisadi ve İdari Bilimler Fakültesi Dergisi, 1(2), 111-126.

Üngüren, E., Doğan, H., Özmen, M., ve Tekin, Ö. A. (2010). Otel çalışanlarının tükenmişlik ve iş tatmin düzeyleri ilişkisi. Journal of Yasar University, 17(5), 2922- 2937.

Vakola, M., ve Bouradas, D. (2005). Antecedents and consequences of organisational silence: an empirical investigation. Employee Relations, 27(5), 441-458.

Walker, A., ve Hutton, D. (2006). The application of the psychlogical contract to workplace safety, Journal of Safety Research, 37(5), 434.

Yaşar, M. (2014). İstatistiğe yönelik tutum ölçeği: geçerlilik ve güvenilirlik çalışması. Pamukkale Üniversitesi Ĕ̆itim Fakültesi Dergisi, 36(2), 59-75.

\section{Kaynakça Bilgisi / Citation Information}

Yılmaz, F. (2020). Örgütsel sessizlik ve tükenmişliğin psikolojik sözleşme ihlali üzerindeki etkilerine yönelik bir araştırma.OPUSUluslararası Toplum Araştırmaları Dergisi, 15(21), 633-658. DOI: 10.26466/opus.594613 